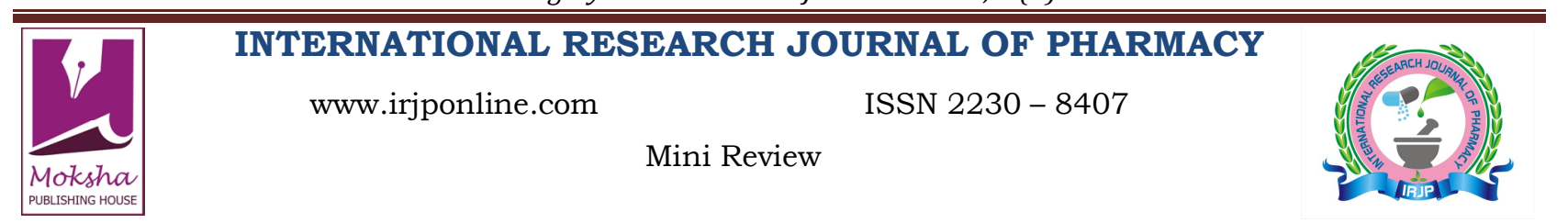

\title{
EFFECT OF INDUCED TOXIC PATHOLOGICAL EFFECT OF PHARMACEUTICAL AGENTS AND HEAVY METALS ON BROILER BIRDS
}

\author{
Ganguly Subha*
}

AICRP On Post Harvest Technology (ICAR), Department of Fish Processing Technology, Faculty of Fishery Sciences, West Bengal University of Animal and Fishery Sciences, 5, Budherhat Road, P.O. Panchasayar, Chakgaria, Kolkata - 700 094, WB, India

*Corresponding Author Email: ganguly38@gmail.com

Article Received on: 18/03/13 Revised on: 01/04/13 Approved for publication: 01/05/13

DOI: $10.7897 / 2230-8407.04507$

IRJP is an official publication of Moksha Publishing House. Website: www.mokshaph.com

(C) All rights reserved.

\section{ABSTRACT}

The indiscriminate and injudicious use of second generation fluoroquinolones viz., enrofloxacin produced anemia, leucopenia, hypoglycaemia, hypoproteinemia, increased enzymatic activity and hepatotoxic and nephrotoxic effects in broiler chickens. Exposure to heavy metals results in congestion and hemorrhages in the lungs, tubular degeneration in kidneys and occasional hemorrhages in the brain. The present article was conducted to review the various pharmaceutical, physiological and toxicopathological effects of different chemical agents and heavy metals due to environmental exposure and through feed on poultry birds.

Key words: Chemical, Exposure, Heavy metal, Poultry birds, Toxic pathology.

\section{INTRODUCTION}

Enrofloxacin is a second generation quinolone derivative which belongs to the group fluoroquinolone. The fluoroquinolones are metabolized in the liver and excreted in urine through the kidney. The liver and kidney develop the highest drug concentration though concentrations in essentially all tissues, including the skeletal and central nervous system reach therapeutic levels. That is why it is relevant to detect the pathological alteration in the visceral tissues and organs. Selenium function is closely associated with Vitamin E. Both have antioxidant property and protect the biological membranes from oxidative degeneration. Glutathione peroxidase is the enzyme which has selenium as its constituent with $4 \mathrm{gm} \mathrm{Se}$ atoms per mole. Out of the total body selenium, 40 per cent is in the enzyme glutathione peroxidase as observed in rats. Both glutathione peroxidase and vitamin E prevent the formation of lipid hydroperoxides which damage the cellular membrane and disturbed the structural integrity of the cells. Selenium and vitamin E are mutually replaceable to some extent but up to a particular limit.

\section{Established research facts}

Cases of acute ciprofloxacin toxicity of birds have been reported earlier by many investigators ${ }^{1,2}$, in human ${ }^{3}$ and in broiler birds ${ }^{4}$. Birds treated with therapeutic dose develop mild diarrhea and depression which simulated the reports ${ }^{3,5}$. Broiler birds of control group had no clinical manifestation at any stage during the experimental period. Anemia in human treated with ciprofloxacin has been reported ${ }^{3,6}$. Broiler birds treated with ciprofloxacin develop leucopenia ${ }^{4}$. Hypoproteinemia in broiler birds treated with overdoses of ciprofloxacin was reported ${ }^{4}$. Niyogi ${ }^{4}$ and Sugawara et $a l^{7}$ also reported an elevated serum enzymatic activity in broiler birds and monkey respectively after therapy with ciprofloxacin both in therapeutic dose and higher doses of the drug. An increased level of serum enzymatic activity is known to occur in a wide range of inflammatory/degenerative disease conditions particularly in hepatic and nephrotic diseases ${ }^{8}$. Salyi et al. ${ }^{9}$ induced acute experimental selenium poisoning in broiler chicks and concluded that oral $\mathrm{LD}_{50}$ of selenium in the form of sodium selenite was $9.7 \mathrm{mg} / \mathrm{kg}$ body weight. Earlier workers ${ }^{9-11}$ has reported significant decline in body weight of selenium fed chickens. The organic form of selenium is known to be accumulated in higher quantities and persist for longer periods in tissues as compared to inorganic toxicity $^{12}$. Increasing trends in the liver concentration of selenium in chicks, hens and cockerels have been reported by other workers. Accumulation of selenium was dose dependent which simulates with the observations of the present study ${ }^{10}$. According to Cousins and Cairney ${ }^{13}$ increased intake of selenium resulted in steady rise in tissue selenium concentrations until levels as high as $5-7 \mathrm{ppm}$ in liver and kidneys. Paul et al. ${ }^{14}$ conducted with sixty healthy day old broiler chicks to determine the effect of induced enrofloxacin toxicity. The birds were divided into four groups keeping the first group as control. Clinically, the broiler birds in all the treatment groups administered with therapeutic dose of enrofloxacin expressed the clinical symptoms of systemic toxicity. Hematological studies indicated that the hemoglobin concentration, packed cell volume, total erythrocyte count and total leukocyte count showed significant variation $(\mathrm{P}<0.01)$ between the treatment groups. Biochemically, all treated groups of birds induced with graded dose level of enrofloxacin, had significantly $(\mathrm{P}<0.01)$ decreased levels of total plasma protein with simultaneous reduction in albumenglobulin $(\mathrm{A}: \mathrm{G})$ ratio than in controls. An investigation was conducted by Kumar et al. ${ }^{15}$ on 300 day-old apparently healthy broiler chicks of either sex procured from a commercial hatchery in Kolkata, India. All the chicks were from the same hatch and also from the same breeding stock. The birds were maintained under standard feeding and management conditions. The oral $\mathrm{LD}_{50}$ of selenium in sodium selenite in broiler chickens is $9.590838 \mathrm{mg}$ per $\mathrm{kg}$ body weight, contained in that compound. The oral $\mathrm{ALD}_{50}$ of sodium selenite was determined by Karber's method and was found to be $9.59038 \mathrm{mg} / \mathrm{kg}$ body weight ${ }^{15}$. 


\section{CONCLUSION}

Based on the review and analysis of physiological effects of different pharmaceutical chemicals and heavy metals, it was suggested that their indiscriminate and injudicious use produces anemia, leucopenia, hypoglycaemia, hypoproteinemia, increased enzymatic activity and hepatotoxic and nephrotoxic effects in broiler chickens. Heavy metals possess high density and toxicity towards living beings. Heavy metals constitute the crust of the earth which resists degradation. Human get inflicted with heavy metals through the agency of food, water and atmosphere. Mercury poisoning by eating fishes is a prominent cause for public health hazard $^{16}$.

\section{REFERENCES}

1. Flanner KDP, Aucoin, Whitt DA, Pras SA. Plasma Concentration of Enrofloxacin in African grey parrots. Avian Dis. 1990; 34: 1017-22. http://dx.doi.org/10.2307/1591399

2. Zhou S, Wang D. Study on acute toxicity of norfloxacin nicotinate in chickens. J Hau Agril Univ. 1994; 13(1): 80-83.

3. Sharma AK, Khosla R, Kela AK, Mehta VL. Fluoroquinolones: Antimicrobial agents of the 90's. Indian J Pharmacol. 1994; 26: 249-61.

4. Niyogi D. Toxic pathology and immune response of broiler chickens induced with ciprofloxacin toxicity, 1999; M.V.Sc thesis submitted to West Bengal University of Animal and Fishery Sciences, India.

5. Norby SR. Side effects of quinolones; comparisons between Quinolones and other antibiotics. European J Clin Microbiol Infect Dis. 1991; 10: 378-83. http://dx.doi.org/10.1007/BF01967014

6. Neu HC. Quinolone antimicrobial agents. Ann Rev Med. 1992; 43: $465-$ 86.http://dx.doi.org/10.1146/annurev.me.43.020192.002341 PMid: 1580602
7. Sugawara T, Yoshida M, Takada S, Miyamoto M., Nomura M. One month oral toxicity study of the new quinolone Antibacterial agent in rats and cynomalgus monkeys. Arzneimitted forschung. 1996; 46(7): 705-10.

8. Hawk PB. Physiological Chemistry. $14^{\text {th }}$ ed.; 1965. p.1124-26. McGraw Hill Book Co., London.

9. Salyi G, Banhidi G, Szabo E, Gonye S, Ratz F. Acute selenium poisoning in broilers. Magy Allatorv Lap. 1993; 48: 22-26. (Vet Bull 64:2969).

10. Khan MZ, Szarek J, Markiowicz, K. Concurrent oral administration of monensin and selenium to broiler chickens: effects on concentrations of different elements in the liver. Acta Vet Hung 1993a; 41: 365-79. (Nutr Abstr Rev 64: 4790).

11. Khan MZ, Szarek J, Krasnodebska-Depta A, Konicicki A. Effect of concurrent administration of lead and selenium on some haematological and biochemical parameters of broiler chickens. Acta vet Hung. 1993b; 41: 123-37 (Nutr Abstr Rev 64: 5060).

12. Rosenfeld I, Beath OA. Selenium. Geobotany, Biochemistry, Toxicity and Nutrition. Academic Press, New York, 1964. PMCid:1927443

13. Cousins FB, Cairney IM. Some aspects of selenium metabolism in sheep. Flust J Agr Res. 1961; 12: 927-42. [cited by Shamberger, 1983]. http://dx.doi.org/10.1071/AR9610927

14. Paul A, Mukhopadhayay SK, Ganguly S, Pal S, Niyogi D. Study on induced enrofloxacin toxicity in broiler birds. Int J Adv Innov Res 2013;2(5): 675-79.

15. Kumar D, Mukhopadhayay SK, Ganguly S, Niyogi D, Jana S, Pal S. Effect of acute selenium toxicity in broiler birds. Int J Adv Innov Res 2013;2(5):680-82.

16. Ganguly S. Human health benefits from fish consumption and, environmental toxicity issues in fish flesh. Int Res J Biol Sci 2013; In press.

\section{Cite this article as:}

Ganguly Subha. Effect of induced toxic pathological effect of pharmaceutical agents and heavy metals on broiler birds. Int. Res. J. Pharm. 2013; 4(5):24-25 